\title{
RANCANG BANGUN SISTEM INFORMASI LAYANAN KONSULTASI BANTUAN HUKUM LPKBH AL-BAIHAQY SURABAYA
}

\author{
Dihin Muriyatmoko ${ }^{1}$, Shoffin Nahwa Utama², Badrus Sholeh ${ }^{3}$ \\ 1,2,3 Teknik Infomatika, Sains dan Teknologi, Universitas Darussalam Gontor \\ ${ }^{1}$ dihin@unida.gontor.ac.id, ${ }^{2}$ shoffin@unida.gontor.ac.id, ${ }^{3}$ badrus@unida.gontor.ac.id
}

\begin{abstract}
Abstrak
Aturan dan bahasa hukum yang terkesan kaku menyulitkan masyarakat tidak mampu dan awam hukum dalam memahami bagaimana memperjuangkan hak keadilannya. Hal ini mendorong Lembaga Pengkajian Konsultan Bisnis dan Bantuan Hukum (LPKBH) Al-Baihaqy Surabaya untuk memberikan layanan konsultasi dan bantuan hukum kepada masyarakat. Layanan konsultasi dan bantuan hukum yang ditawarkan LPKBH Al-Baihaqy dapat didapatkan dengan mendatangi kantor lembaga. Sedangkan, kesibukan masyarakat dalam aktivitas, kemungkinan sedikit kesempatan untuk pergi berkonsultasi di lembaga bantuan hukum atau di rumah praktik pengacara. Selain itu, keberadaan lembaga ini tidak begitu dikenal karena jangkauan pasar yang kecil. Keadaan ini membuat LPKBH Al-Baihaqy menginginkan untuk menghadirkan layanan konsultasi yang dapat dilakukan secara online dengan memanfaatkan teknologi informasi. Penelitian ini menghadirkan solusi dengan membangun sebuah sistem informasi yang mempermudah layanan konsultasi dan bantuan hukum di LPKBH Al-Baihaqy Surabaya secara transparan dan memberikan layanan konsultasi gratis kepada masyarakat yang kurang mampu. Sistem berbasis web dan dibangun dengan bahasa pemrograman PHP menggunakan kerangka kerja Codeigniter. Penelitian ini bertujuan untuk mempermudah masyarakat yang ingin berkonsultasi tentang masalah hukum dengan LPKBH AlBaihaqy Surabaya melalui media online. Penelitian menghasilkan tiga fitur layanan, yaitu konsultasi online, konsultasi tatap muka, dan penanganan hukum. Aplikasi diimplementasikan dan diunggah ke hosting dengan domain ruanglawyer.com. Analisa kepuasan responden menunjukkan rata-rata berada pada 4.43 dari skala lima yang berarti sistem informasi layanan konsultasi bantuan hukum ini memberikan kepuasan kepada pengguna.
\end{abstract}

Kata kunci : Layanan Konsultasi, Bantuan Hukum, Al-baihaqy, Konsultasi Hukum Gratis, LPKBH

\section{Pendahuluan}

Bantuan hukum merupakan suatu media yang dapat digunakan oleh semua orang dalam rangka menuntut haknya atas adanya perlakuan yang tidak sesuai dengan kaedah hukum yang berlaku (Arif, 2016). Aturan dan bahasa hukum yang terkesan kaku menyulitkan masyarakat tidak mampu dan awam hukum dalam memahami bagaimana memperjuangkan hak keadilannya (Rosyada, Warassih, \& Herawati, 2018). Hal ini menyebabkan Lembaga Pengkajian Konsultan Bisnis dan Bantuan Hukum (LPKBH) Al-Baihaqy Surabaya menginginkan masyarakat yang tidak mampu dan awam mendapatkan pemahaman hukum melalui konsultasi.

Layanan yang ditawarkan LPKBH AlBaihaqy bisa didapatkan dengan mendatangi kantor lembaga. Sedangkan kesibukan masyarakat dalam aktivitas sehari-hari dan waktu luang yang sedikit kemungkinan tidak memberikan kesempatan untuk pergi berkonsultasi di lembaga bantuan hukum atau di rumah praktik pengacara. Selain itu, keberadaan lembaga ini tidak begitu dikenal karena jangkauan pasar yang kecil. Keadaan ini membuat LPKBH Al-Baihaqy menghadirkan layanan konsultasi yang dapat dilakukan secara online. Pemanfaatan teknologi informasi dapat mempermudah masyarakat untuk berkonsultasi di mana saja dan kapan saja. Teknologi mampu membantu mempermudah dalam semua bidang (Lestari, 2018). Orang yang mampu secara finansial sangat mudah untuk mendapatkan jasa hukum dari seorang advokad, namun rakyat miskin dirasa sangat sulit untuk mendapatkan bantuan hukum. Advokat dan lembaga bantuan hukum mempunyai peran penting dalam pemerataan keadilan, sehingga orang kaya atau orang miskin mendapatkan pembelaan yang sama dan pengakuan yang sama di hadapan hukum (Setyowati \& Muchiningtias, 2018)(Dewi \& Agustin, 2011).

Masyarakat tidak seharusnya mendapatkan penanganan hukum yang tidak bersih. LPKBH AlBaihaqy tidak menginginkan adanya biaya tambahan dari advokat. Tujuan penelitian ini adalah mempermudah jangkauan masyarakat terhadap LPKBH Al-Baihaqy dengan memberikan jasa konsultasi hukum gratis kepada masyarakat dan layanan advokasi. Tabel 1 menunjukkan perbandingan dengan penelitian sejenis yang berisi masalah, metode, dan hasil penelitian. Tabel 1 juga menampilkan analisis gap dengan membandingkan penelitian sekarang. 
Tabel 1. Kajian Pustaka dan Gap Analisis

\begin{tabular}{|c|c|c|c|c|c|}
\hline No & Penulis & Permasalahan & Metode & Hasil Penelitian & $\begin{array}{c}\text { Gap dengan } \\
\text { Penelitian Sekarang }\end{array}$ \\
\hline 1 & $\begin{array}{l}\text { Maulana Malik } \\
\text { (Malik, 2017) }\end{array}$ & $\begin{array}{l}\text { Penataan dan } \\
\text { penyimpanan } \\
\text { dokumentasi } \\
\text { kasus belum } \\
\text { dikelola dengan } \\
\text { baik. }\end{array}$ & Eksperimental & $\begin{array}{l}\text { Sistem } \\
\text { manajemen pengelolaan } \\
\text { dan penjadwalan layanan } \\
\text { konsultasi bantuan hukum } \\
\text { pada LBH Makassar }\end{array}$ & \begin{tabular}{lr} 
Dokumentasi & kasus \\
disimpan dalam sistem \\
berdasarkan tanggal \\
dan tidak terdapat \\
antrian jasa sehingga \\
dapat digunakan secara \\
\multicolumn{2}{l}{ daring masal } \\
\end{tabular} \\
\hline 2 & $\begin{array}{l}\text { Irwan dkk (Irwan, } \\
\text { Gustientiedina, } \\
\text { Sunarti, \& } \\
\text { Desnelita, 2017) }\end{array}$ & \begin{tabular}{ll}
\multicolumn{2}{l}{ Kebingungan } \\
siswa & SMK \\
terhadap & Karir \\
yang & akan \\
diambil. &
\end{tabular} & $\begin{array}{l}\text { Certainty } \\
\text { Factor }(\mathrm{CF})\end{array}$ & $\begin{array}{lr}\text { Rancangan } & \text { software } \\
\text { bimbingan } & \text { dan } \\
\text { pengembangan karier } \\
\text { siswa. Layanan yang } \\
\text { ditawarkan adalah jasa } \\
\text { bantuan yang dirancang } \\
\text { berbasis web sehingga } \\
\text { memudahkan siswa dalam } \\
\text { melakukan bimbingan } \\
\text { karier }\end{array}$ & \multirow{4}{*}{$\begin{array}{lr}\text { User } & \text { melakukan } \\
\text { konsultasi } & \text { secara } \\
\text { langsung } & \text { dengan } \\
\text { konsultan } & \text { melalui } \\
\text { percakapan daring pada } \\
\text { aplikasi dan } & \text { user bisa } \\
\text { mendapatkan } & \\
\text { penanganan } & \text { ke } \\
\text { lapangan } & \end{array}$} \\
\hline 3 & $\begin{array}{l}\text { Kunti Dwi } \\
\text { Narwattu Jati dkk } \\
\text { (Jati \& Handaga, } \\
\text { 2017) }\end{array}$ & $\begin{array}{l}\text { Kesibukan } \\
\text { masyarakat dan } \\
\text { sedikitnya waktu } \\
\text { luang menjadikan } \\
\text { mereka kurang } \\
\text { peduli dengan } \\
\text { gizi. }\end{array}$ & Waterfall & $\begin{array}{l}\text { Aplikasi konsultasi } \\
\text { kesehatan yang } \\
\text { menyediakan informasi } \\
\text { kesehatan gizi dan } \\
\text { informasi kesehatan antara } \\
\text { lain berat badan ideal, } \\
\text { status gizi, jumlah } \\
\text { kebutuhan kalori, beberapa } \\
\text { artikel kesehatan, rencana } \\
\text { menu makanan, dan } \\
\text { keadaan gizi tubuh. }\end{array}$ & \\
\hline 4 & $\begin{array}{l}\text { Sri Hartati dkk } \\
\text { (Hartati, Kristiana } \\
\text { Dewi, Puastuti, } \\
\text { Muslihudin, \& } \\
\text { Setio Budi, 2017) }\end{array}$ & $\begin{array}{l}\text { Kesulitan jalinan } \\
\text { laju komunikasi } \\
\text { di antara berbagai } \\
\text { pihak yang } \\
\text { terkait didalam } \\
\text { proses } \\
\text { perkuliahan di } \\
\text { STMIK } \\
\text { Pringsewu. } \\
\text { Komunikasi } \\
\text { secara } \\
\text { konvensional } \\
\text { kurang eficien. }\end{array}$ & $\begin{array}{l}\text { R\&D } \\
\text { (Reseach and } \\
\text { Development) }\end{array}$ & $\begin{array}{l}\text { Aplikasi komunikasi } \\
\text { (percakapan) berbasis web } \\
\text { dan android. Dari hasil uji } \\
\text { coba dari } 100 \text { mahasiswa } \\
\text { dan dosen yang terdiri dari } \\
\text { tiga kelas, kuesioner } \\
\text { menunjukkan pengguna } \\
\text { menyukai aplikasi ini di } \\
\text { atas } 80 \% \text {. }\end{array}$ & \\
\hline 5 & $\begin{array}{l}\text { Arif Harjanto dkk } \\
\text { (Harjanto, } \\
\text { Karnila, \& } \\
\text { Nugraha, 2018) }\end{array}$ & $\begin{array}{l}\text { Menurunnya tata } \\
\text { krama sosial dan } \\
\text { etika moral } \\
\text { dalam praktek } \\
\text { kehidupan } \\
\text { sekolah yang } \\
\text { mengakibatkan } \\
\text { sejumlah negatif } \\
\text { peristiwa na amat } \\
\text { yang } \\
\text { merisaukan } \\
\text { masyarakat. }\end{array}$ & $\begin{array}{l}\text { Forward } \\
\text { chaining }\end{array}$ & $\begin{array}{l}\text { Rancang bangun yang di } \\
\text { fasilitasi sebuah Program } \\
\text { sistem pakar bermanfaat } \\
\text { untuk } \\
\text { mengkonsultasi perilaku } \\
\text { pada siswa dan digunakan } \\
\text { mengetahui strategi } \\
\text { penanganan } \\
\text { keputusan yang harus } \\
\text { dilakukan oleh guru } \\
\text { bimbingan konseling di } \\
\text { sekolah guna menangani } \\
\text { perilaku siswa. }\end{array}$ & \\
\hline
\end{tabular}




\section{Metodologi Penelitian}

\subsection{Tahapan Penelitian}

Dalam melakukan penelitian, terdapat beberapa tahapan yang dilakukan peneliti untuk mengembangkan sistem agar sesuai dengan rencana dan kebutuhan LPKBH Al-Baihaqy atau pengguna. gambar 1 menunjukkan alur tahapan penelitian.

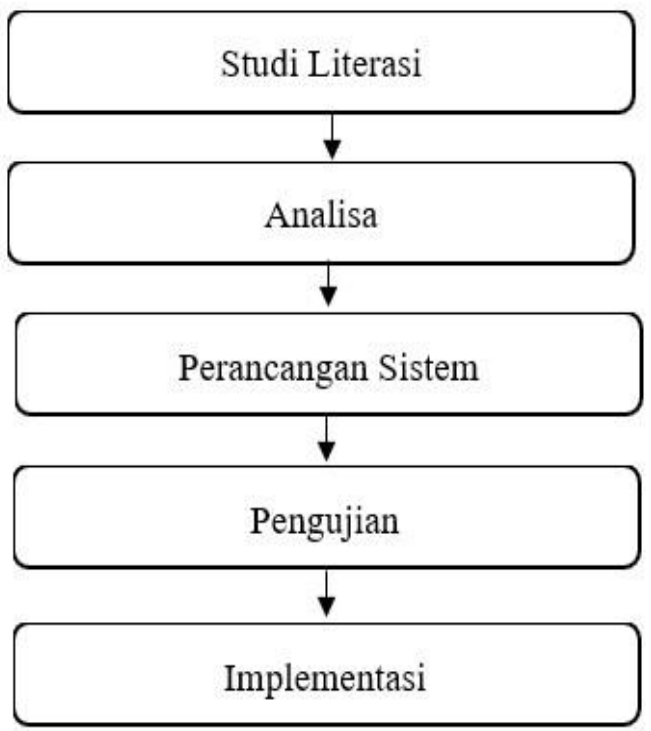

Gambar 1. Tahapan Penelitian

\section{a. Studi Literatur}

Tahap pertama melakukan penelusuran terhadap penelitian-penelitian terdahulu dan beberapa sumber lainnya untuk dijadikan referensi pada penelitian saat ini. Penelitian yang sudah ada dapat dikembangkan agar lebih baik.

\section{b. Analisa}

Tahap selanjutnya adalah menganalisis masalah yang ada di LPKBH Al-Baihaqy Surabaya kemudian dijadikan peluang untuk mendukung dalam penentuan fitur yang dapat dikembangkan ke dalam sistem informasi konsultasi dan bantuan hukum di LPKBH Al-Baihaqy.

\section{c. Perancangan Sistem}

Pada tahap ini, peneliti merancang alur kerja atau diagram yang dibutuhkan untuk pengerjaan program. Sebelum menulis program, peneliti terlebih dahulu mendesain rancangannya agar pengerjaan proyek sistem informasi konsultasi dan bantuan hukum ini akan lebih mudah. Selain itu, peneliti juga mendesain front-end dan merancang relasi database yang akan diintegrasikan dengan bahasa pemrograman PHP sebagai back-end.

\subsection{Perancangan Use Case Diagram}

Use case diagram adalah sebuah kegiatan yang dilakukan oleh sistem, biasa dalam menanggapi permintaan dari pengguna sistem. Diagram ini menunjukkan batas penggunaan aktor. Terdapat dua elemen yang harus digambarkan pada sebuah use case diagram, yaitu aktor dan use case. Aktor adalah elemen yang berinteraksi dengan sistem. Berikut ini deskripsi aktor yang ada pada sistem:

a. Admin; pihak LPKBH Al-Baihaqy yang memiliki hak mengelola informasi dan sebagai penghubung antara aktor Client dan Lawyer.

b. Lawyer; mitra yang memberikan jasa konsultasi dan bantuan hukum kepada Client.

c. Client; pihak yang memperoleh layanan konsultasi dan bantuan hukum.

Berikut use case sistem berdasarkan kelas sistem:

1) Use Case Kelas Sistem Akun

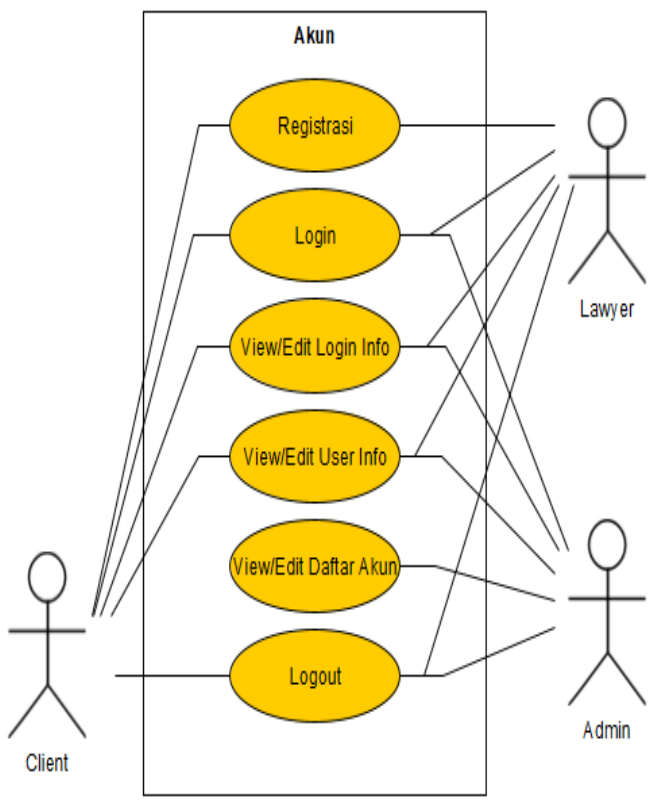

Gambar 2. Use Case Sistem Akun

Gambar 2 menjelaskan bagaimana use case pada sistem akun. Kelas sistem akun menunjukkan sesi dari pengguna. Dalam sistem informasi ini, pengguna harus memiliki akun untuk mendapatkan akses layanan atau aktivitas sesi. Berikut ini penjelasan dari masing-masing case:

a. Registrasi; memungkinkan pengguna untuk mendaftar sebagai akun baru pada sistem.

b. Login; upaya user untuk masuk ke sistem.

c. View/Edit Login Info; Aktor dapat melihat dan merubah info login seperti password, nomor telepon dan foto profil. 
d. View/Edit User Info; Aktor dapat melihat dan memperbarui info login seperti alamat, bidang (lawyer), profesi (client) dan tanggal lahir.

e. View/Edit Daftar akun; Use case ini dapat melihat atau memperbarui akun setiap user.

f. Logout; memungkinkan semua user dapat keluar dari sesi login.

2) Use Case Kelas Sistem Konsultasi

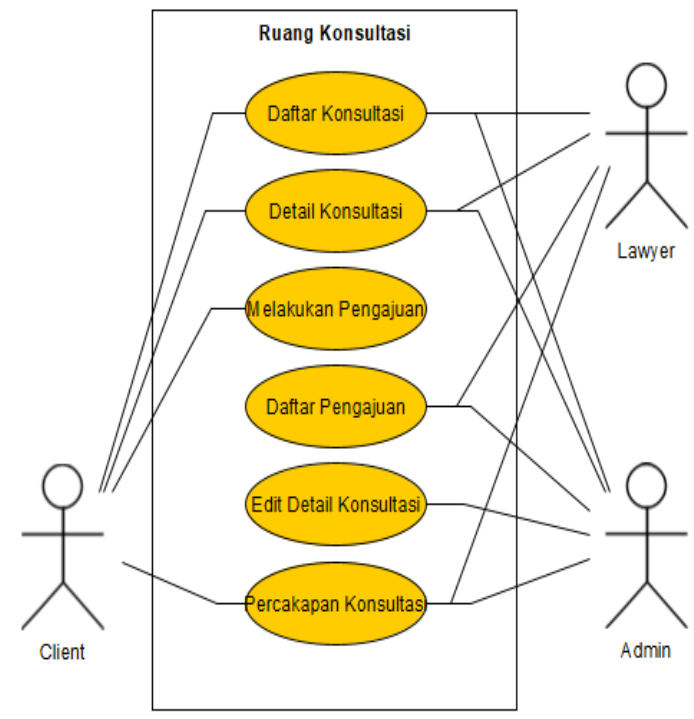

Gambar 3. Use Case Ruang Konsultasi

Kelas sistem ruang konsultasi digambarkan oleh gambar 3. kelas sistem ini memiliki dua cakupan layanan, yaitu konsultasi online dan konsultasi tatap muka. Penjelasan deskripsi dari use case di atas diuraikan sebagai berikut:

a. Daftar Konsultasi; melihat daftar semua konsultasi.

b. Detail Konsultasi; dari halaman daftar konsultasi, aktor bisa melihat detail konsultasi yang dipilih.

c. Melakukan Pengajuan; Client melakukan pengajuan konsultasi online/tatap muka.

d. Daftar pengajuan; pengajuan yang masuk pada sistem ditampilkan pada use case ini.

e. Edit Detail Konsultasi; use case ini memungkinkan admin untuk memperbarui detail konsultasi

f. Percakapan Konsultasi Online; fitur utama dari sistem informasi ini. Halaman ini yang menghubungkan lawyer dan client untuk melakukan konsultasi.

3) Use Case Kelas Sistem Penanganan

Selanjutnya adalah use case kelas sistem penanganan, gambar 4. Pada kelas ini, lawyer hanya memiliki akses terhadap daftar penanganan. Berikut ini deskripsi dari use case di atas: a. Pengajuan Penanganan; melakukan mengajukan penanganan.

b. Detail Konsultasi; aktor dapat melihat detail konsultasi yang dipilih.

c. Melakukan Pengajuan; client melakukan pengajuan konsultasi online/tatap muka.

d. Daftar Pengajuan; pengajuan yang masuk pada sistem ditampilkan pada use case ini.

e. Edit Detail Konsultasi; use case ini memungkinkan admin untuk memperbarui detail konsultasi

f. Percakapan Konsultasi; use case ini merupakan fitur utama dari sistem informasi ini. Halaman ini yang menghubungkan lawyer dan client untuk melakukan konsultasi.

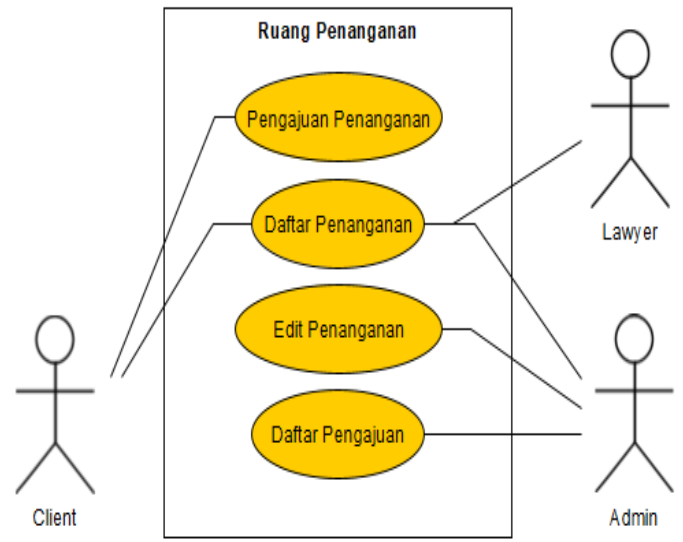

Gambar 4. Use Case Ruang Penanganan

4) Use Case Kelas Sistem Tagihan dan Pembayaran

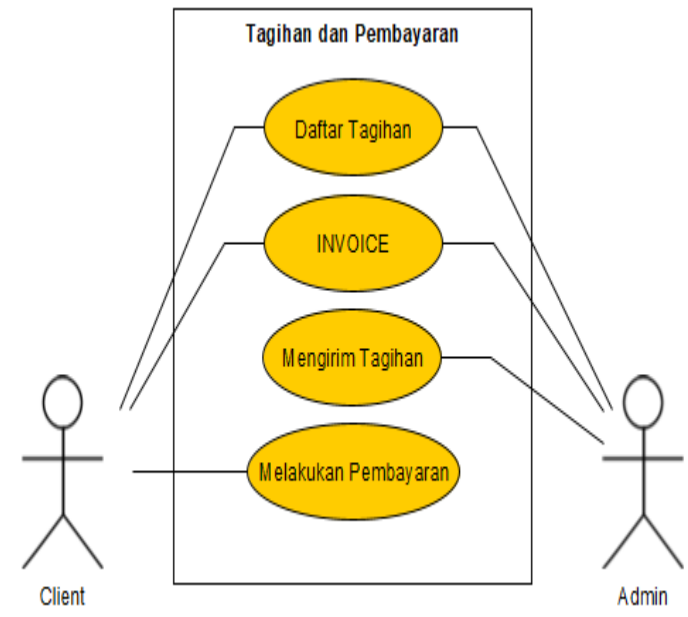

Gambar 5. Use Case Tagihan dan Pembayaran

Gambar 5 menunjukkan gambaran use case untuk tagihan dan pembayaran. Dalam hal ini, kelas hanya meliputi aktor admin dan client. Deskripsi berikut ini menjelaskan use case di atas: 
a. Daftar Tagihan; use case untuk melihat daftar tagihan.

b. Invoice; use case ini menunjukkan keterangan dan jumlah tagihan

c. Mengirim Tagihan; admin membuat tagihan

d. Melakukan Pembayaran; client dapat melakukan pembayaran pada use case ini.

\subsection{Flowchart}

Flowchart adalah untuk menyederhanakan rangkaian proses atau prosedur untuk memudahkan pemahaman pengguna terhadap informasi tersebut (Soeherman \& Pinontoan, 2018). Pada sistem informasi pelayanan konsultasi bantuan hukum ini terdapat tiga fitur utama, yaitu konsultasi online, konsultasi tatap muka, dan penanganan.

\section{1) Konsultasi Online}

Fitur konsultasi online memungkinkan client dan lawyer melakukan konsultasi melalui percakapan secara daring. Flowchart fitur ini disajikan dalam gambar 6.

2) Konsultasi Tatap Muka

Selain melakukan konsultasi melalui percakapan daring, client juga dapat memilih layanan konsultasi tatap muka. Client dapat bertemu dengan lawyer secara langsung untuk mengonsultasikan perkaranya. Flowchart konsultasi tatap muka dinyatakan pada gambar 7 .

\section{3) Penanganan}

Layanan penanganan adalah pelayanan tambahan jika client membutuhkan lawyer untuk mendampinginya dalam perkaranya. Layanan ini ditawarkan oleh admin setelah layanan konsultasi berakhir. Langkah kerja dari layanan penanganan dijelaskan dalam gambar 8 .

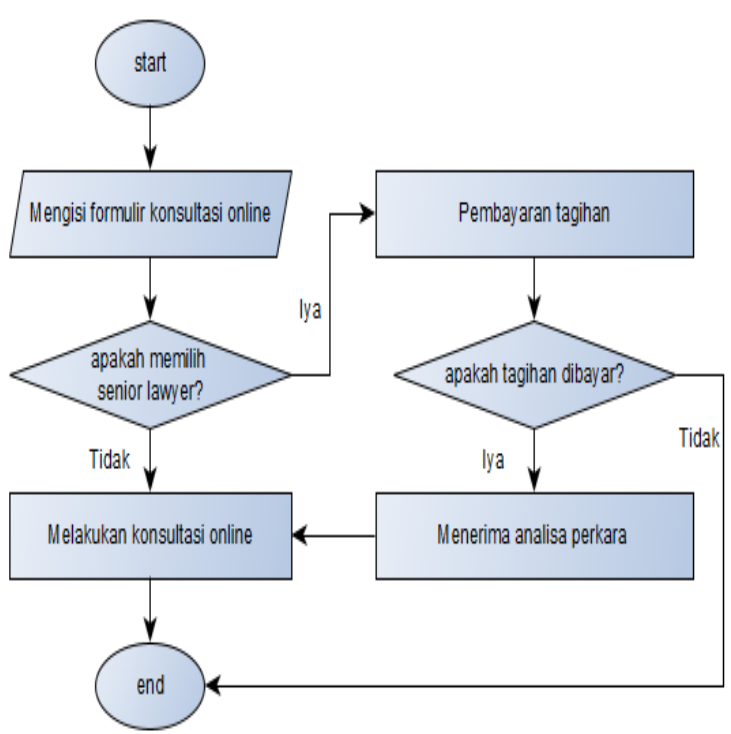

Gambar 6. Flowchart Konsultasi Online

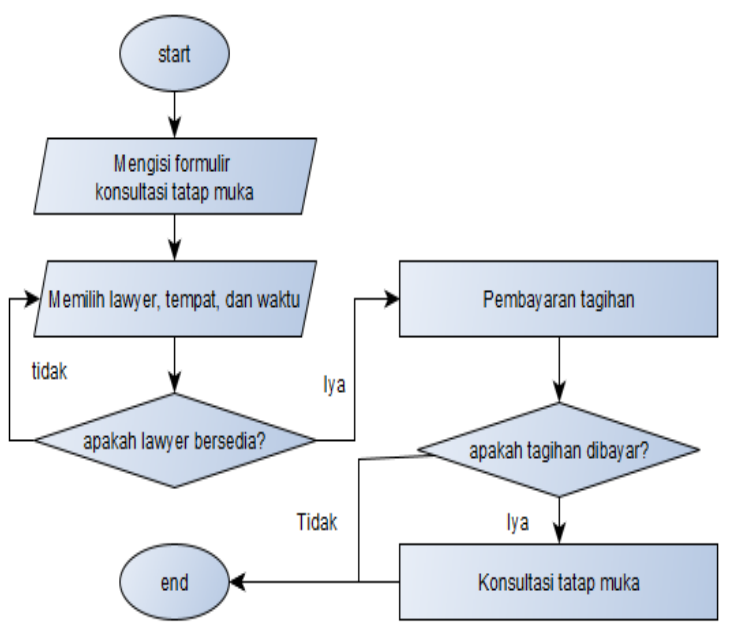

Gambar 7. Flowchart Konsultasi Tatap Muka

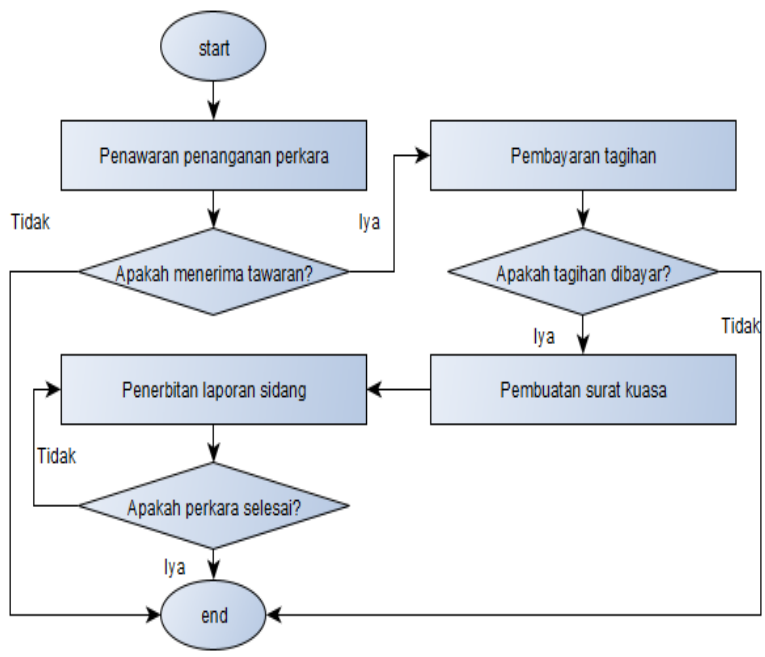

Gambar 8. Flowchart Penanganan

\section{d. Pengujian}

Setelah sistem dibangun, tahap selanjutnya adalah menguji dan memastikan sistem memiliki kinerja dan fungsi yang sesuai dengan tujuan penelitian. Untuk mengukur tingkat kepuasan pengguna, penelitian ini menggunakan metode framework PIECES. Kerangka kerja PIECES adalah kerangka kerja yang digunakan untuk mengklasifikasikan suatu problem, opportunities, dan directives yang terdapat pada bagian scope definition analisa dan perancangan sistem (Mustaqbal, Firdaus, \& Rahmadi, 2015).

\section{e. Implementasi}

Setelah sistem melawati tahap pengujian, sistem diunggah ke internet dan siap digunakan sebagaimana tujuan penelitian ini ditulis. 


\section{Hasil dan Pembahasan}

\subsection{Hasil Website}

1) Beranda

Halaman beranda dapat diakses oleh semua tingkatan pengguna bahkan dari luar sesi pengguna. Gambar 9 menampilkan halaman beranda yang digunakan untuk menampilkan informasi dan latar belakang aplikasi.

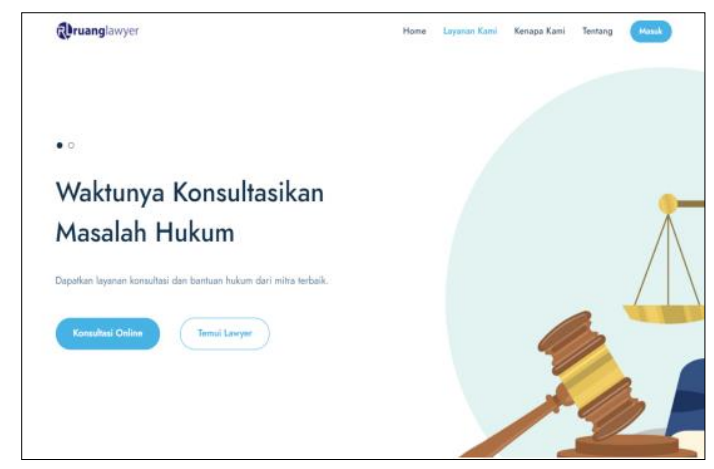

Gambar 9. Halaman Beranda

\section{2) Daftar Menu}

Ada tiga tingkatan pengguna pada sistem informasi layanan konsultasi bantuan hukum ini, yaitu admin, lawyer, dan client. Setiap tingkatan mempunyai daftar menu yang berbeda. Daftar menu di setiap halaman berada di samping kiri halaman (sidebar). Sidebar memudahkan pengguna berpindah dari halaman ke halaman yang lain.

a. Admin

Tingkatan pengguna pertama, admin, mempunyai daftar menu paling banyak. Admin mempunyai hak akses lebih banyak dari tingkatan pengguna lainnya. Pada gambar 10 menampilkan daftar menu pada admin yaitu dashboard, daftar konsultasi, tagihan, daftar pengguna.

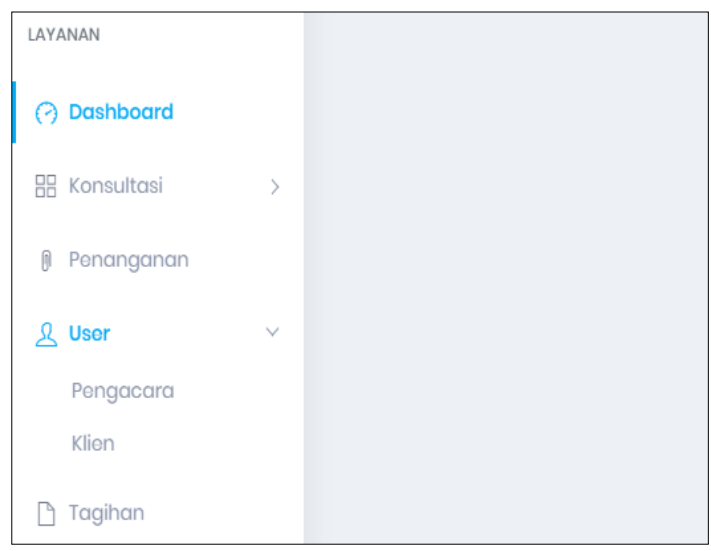

Gambar 10. Mепи Admin

b. Lawyer

Pengguna Lawyer memiliki sedikit daftar menu karena tingkatan pengguna ini hanya memiliki akses untuk layanan. Menu akses lawyer ditunjukkan gambar 11 .

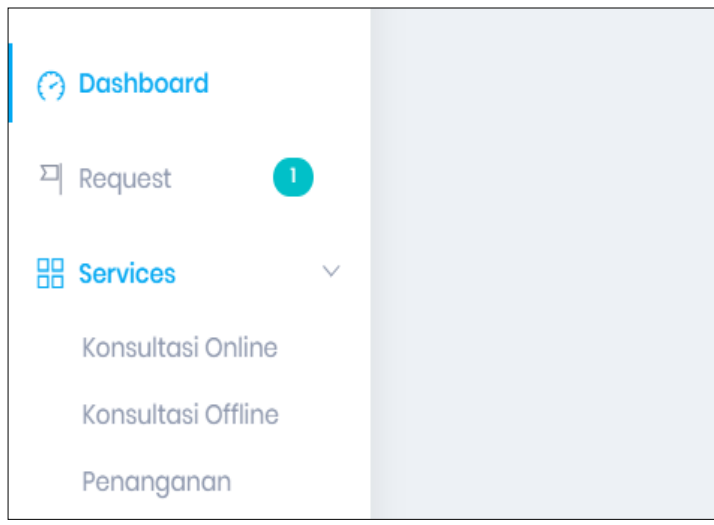

Gambar 11. Menu Lawyer

\section{c. Client}

Pada gambar 12 di bawah, terdapat daftar menu yang menunjukkan bahwa tingkatan pengguna Client sebagai customer. Menu yang terdapat pada pengguna Client merupakan menu-menu dasar klien seperti daftar layanan dan tagihan.

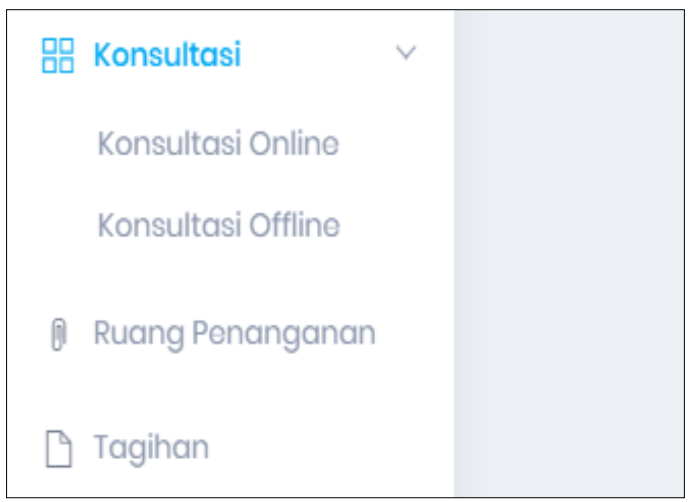

Gambar 12. Menu Client

\subsection{Pembahasan Kepuasan Pengguna}

Analisa kepuasan pengguna bertujuan untuk mengetahui tanggapan dan kepuasan pengguna terhadap sistem yang dibangun. Pengujian ini dilakukan dengan cara peneliti memberikan kuesioner kepada beberapa staf di LPKBH AlBaihaqy sebagai pengguna. Pengguna diberikan akun akses dan dipilih sesuai kapabilitas terhadap salah satu peran aktor, yaitu admin, lawyer, dan client. Berikut ini jumlah berdasarkan jenis responden yang melakukan uji coba terhadap sistem;

a. Admin (staf lembaga): 4 Responden

b. Lawyer (pengacara): 3 Responden

c. Client (umum): 10 Responden

Setiap pertanyaan yang diajukan diberikan klasifikasi nilai dengan menggunakan skala likert yang terdiri dari lima kategori nilai sebagai berikut;

a. Sangat Setuju (SS)

b. Setuju (S) 
c. Netral (N)

d. Tidak Setuju (TS)

e. Sangat Tidak Setuju (STS)

Peneliti memberikan akun kepada para responden disertai dengan beberapa pernyataan untuk mengetahui kemudahan dan fungsi sistem dalam penelitian ini.

Dalam penyebaran kuesioner kepada pengguna, peneliti menggunakan kerangka kerja PIECES. Kerangka kerja PIECES adalah kerangka kerja yang digunakan untuk mengklasifikasikan suatu problem, opportunities, dan directives yang terdapat pada bagian scope definition analisa dan perancangan sistem, sama seperti yang dilakukan dalam penelitian (Tullah \& Hanafri, 2014), (Sidiq \& Kurniawati, 2019) dan (Supriyatna \& Maria, 2018). Berikut ini enam indikator framework PIECES disertai pernyataan kuesionernya;

a. Performance

- Aplikasi memenuhi kebutuhan pengguna

- Aplikasi memberikan waktu loading yang cepat

- Aplikasi menyajikan menu dalam format yang sesuai

- Aplikasi memiliki tampilan yang menarik

- Aplikasi memberikan kemudahan untuk dioperasikan

- Aplikasi memberikan penataan huruf yang jelas sehingga mudah dipahami

b. Information and Data

- Aplikasi menyediakan informasi yang tepat dan akurat

- Informasi yang disajikan sesuai dengan kebutuhan pengguna

- Tepat dalam penyusunan tata letak informasi

- Aplikasi menyediakan informasi terkini

c. Economics

- Domain aplikasi sangat mudah diingat

- Aplikasi dapat meringankan pengguna dari segi waktu, biaya dan tenaga

- Penggunaan aplikasi berperan dalam hal peningkatan perusahaan/lembaga

d. Control and Security

- Aplikasi memberikan Batasan akses bagi pengguna

- Aplikasi menjamin kerahasiaan data profil pengguna

- Aplikasi menjamin keamanan data pada saat melakukan upload

- Aplikasi menjamin keamanan pada saat download

e. Efficiency

- Aplikasi memberikan pandu arah yang jelas sehingga mudah dipahami

- Desain aplikasi secara keseluruhan sudah baik sehingga mudah dimengerti

- Saya tidak menemukan kesulitan dalam menggunakan aplikasi ketika pertama kali dibuka f. Service

- Aplikasi mudah dipelajari dan dipahami

- Aplikasi mudah digunakan

- Aplikasi tidak pernah mengalami gangguan (dalam hal pengaksesan tidak adanya error)

- Aplikasi dapat diakses baik dari PC, Tablet, hingga Handphone

Berdasarkan hasil penilaian kuesioner terhadap pengguna sistem dengan menggunakan skala likert untuk mengetahui tingkat kepuasan pengguna sesuai dengan pilihan jawaban dan skor, maka digunakan rumus untuk mendapatkan rata-rata peringkat kepuasan:

$$
R K=\frac{J S K}{J K}
$$

Keterangan:

RK = Rata-rata Kuesioner

JSK = Jumlah Skor Kuesioner

$\mathrm{JK}=$ Jumlah Kuesioner

Sedangkan untuk menentukan tingkat kepuasan, peneliti menggunakan model yang didefinisikan oleh Kaplan dan Norton (Asbar \& Saptari, 2017) pada tabel 2.

Tabel 2. Rentang Nilai

\begin{tabular}{|c|l|l|}
\hline No & \multicolumn{1}{|c|}{ Rentang Nilai } & \multicolumn{1}{c|}{ Kesimpulan } \\
\hline 1 & $4.92-5$ & Sangat Puas \\
\hline 2 & $3.4-4.91$ & Puas \\
\hline 3 & $2.6-3.39$ & Cukup Puas \\
\hline 4 & $1.8-2.59$ & Tidak Puas \\
\hline 5 & $1-1.79$ & Sangat Tidak Puas \\
\hline
\end{tabular}

Dengan ketentuan tingkat kepuasan seperti di atas, maka hasil penilaian disajikan pada tabel 3 .

Tabel 3. Respons Responden

\begin{tabular}{|l|l|l|l|l|l|}
\hline Respons & SS & S & N & TS & STS \\
\hline Skor & 5 & 4 & 3 & 2 & 1 \\
\hline R1 & 9 & 8 & 0 & 0 & 0 \\
\hline R2 & 8 & 9 & 0 & 0 & 0 \\
\hline R3 & 7 & 10 & 0 & 0 & 0 \\
\hline R4 & 7 & 8 & 2 & 0 & 0 \\
\hline R5 & 7 & 7 & 3 & 0 & 0 \\
\hline R6 & 7 & 9 & 1 & 0 & 0 \\
\hline R7 & 8 & 9 & 0 & 0 & 0 \\
\hline R8 & 8 & 9 & 0 & 0 & 0 \\
\hline R9 & 5 & 11 & 1 & 0 & 0 \\
\hline R10 & 7 & 9 & 1 & 0 & 0 \\
\hline R11 & 8 & 7 & 2 & 0 & 0 \\
\hline R12 & 9 & 8 & 0 & 0 & 0 \\
\hline R13 & 9 & 8 & 0 & 0 & 0 \\
\hline & & & & & \\
\hline
\end{tabular}




\begin{tabular}{|l|l|l|l|l|l|}
\hline Respons & SS & S & N & TS & STS \\
\hline Skor & 5 & 4 & 3 & 2 & 1 \\
\hline R14 & 6 & 8 & 3 & 0 & 0 \\
\hline R15 & 11 & 6 & 0 & 0 & 0 \\
\hline R16 & 11 & 5 & 1 & 0 & 0 \\
\hline R17 & 12 & 5 & 0 & 0 & 0 \\
\hline R18 & 11 & 5 & 1 & 0 & 0 \\
\hline R19 & 9 & 7 & 1 & 0 & 0 \\
\hline R20 & 7 & 8 & 2 & 0 & 0 \\
\hline R21 & 10 & 7 & 0 & 0 & 0 \\
\hline R22 & 8 & 9 & 0 & 0 & 0 \\
\hline R23 & 7 & 6 & 4 & 0 & 0 \\
\hline R24 & 10 & 6 & 1 & 0 & 0 \\
\hline Total & 201 & 184 & 23 & 0 & 0 \\
\hline
\end{tabular}

$\mathrm{RK}=\frac{(5 * 201)+(4 * 184)+(3 * 23)+(2 * 0)+(1 * 0)}{408}$

$\mathbf{R K}=\frac{1810}{408}=4.43$

Berdasarkan hasil perhitungan jumlah ratarata tingkat kepuasan diperoleh bernilai 4.43, maka dapat disimpulkan bahwa tingkat kepuasan pengguna terhadap sistem informasi yang dibangun termasuk dalam kategori PUAS. Hal ini menunjukkan indikasi positif, pengguna merasa puas atas sistem informasi layanan konsultasi bantuan hukum ini.

\section{Kesimpulan}

Hasil pengembangan sistem informasi layanan konsultasi bantuan hukum diimplementasikan ke hosting dengan domain http://ruanglawyer.com sejak tanggal 12 Maret 2020. Sistem dapat dijangkau masyarakat dengan mudah kapan saja dan di mana saja dari berbagai platform. Layanan yang ditawarkan adalah konsultasi online, konsultasi tatap muka, dan penanganan hukum. Masyarakat yang kurang mampu dapat mengajukan konsultasi online secara gratis dengan pengacara-pengacara muda, mitra LPKBH Al-Baihaqy. Mitra LPKBH Al-Baihaqy di bawah Yayasan Pondok Entrepreneur Al-Baihaqy adalah pengacara pilihan, yang merupakan anggota yayasan pondok, dan memungkinkan kemudahan koordinasi admin terhadap pengacara. Penelitian selanjutnya bisa dikembangkan berbasiskan media smartphone (mobile).

\section{Daftar Pustaka}

Arif, A. R. (2016). PELAKSANAAN PEMBERIAN BANTUAN HUKUM

TERHADAP TERDAKWA YANG TIDAK MAMPU DALAM PERKARA PIDANA DI KOTA BANDAR LAMPUNG. FIAT JUSTISIA:Jurnal Ilmu Hukum, 9(1). https://doi.org/10.25041/fiatjustisia.v9no1.59 1

Asbar, Y., \& Saptari, M. A. (2017). Analisa Dalam Mengukur Kualitas Pelayanan Terhadap Kepuasan Konsumen Menggunakan Metode PIECES. Jurnal Visioner \& Strategis, 6(2), 39-47.

Dewi, R. S., \& Agustin, V. Y. (2011). Peran Lembaga Bantuan Hukum "Kartini” Dalam Menjamin Dan Memenuhi Hak Rakyat Miskin Untuk Mendapatkan Akses Keadilan Di Dalam Proses Peradilan. Kartini, 1(1), 1.

Harjanto, A., Karnila, S., \& Nugraha, F. (2018). RANCANG BANGUN APLIKASI SISTEM PAKAR UNTUK KONSULTASI PERILAKU SISWA DI SEKOLAH MENGGUNAKAN METODE FORWARD CHAINING. Simetris: Jurnal Teknik Mesin, Elektro Dan Ilmu Komputer, 9(2), 817-824. https://doi.org/10.24176/simet.v9i2.2367

Hartati, S., Kristiana Dewi, N. A., Puastuti, D., Muslihudin, M., \& Setio Budi, N. (2017). Sistem Aplikasi EDUCHAT STMIK PRINGSEWU Berbasis ANDROID Sebagai Media Komunikasi dan Informasi. Jurnal Nasional Teknologi Dan Sistem Informasi, $3(1)$, $143-152$. https://doi.org/10.25077/TEKNOSI.v3i1.201 7.143-152

Irwan, I., Gustientiedina, G., Sunarti, S., \& Desnelita, Y. (2017). Perancangan Software Bimbingan dan Pengembangan Karir Siswa dalam Pengambilan Keputusan dan Konsultasi. Jurnal Teknologi Informasi Dan Ilmu Komputer, 4(4), 237. https://doi.org/10.25126/jtiik.201744464

Jati, K. D. N., \& Handaga, B. (2017). Rancang Bangun Aplikasi Konsultasi Kesehatan Online (Universitas Muhammadiyah Surakarta). Universitas Muhammadiyah Surakarta. Retrieved from http://eprints.ums.ac.id/49019/

Lestari, S. (2018). Peran Teknologi dalam Pendidikan di Era Globalisasi. EDURELIGIA; JURNAL PENDIDIKAN AGAMA ISLAM, 2(2),

94-100. https://doi.org/10.33650/edureligia.v2i2.459

Malik, M. (2017). Rancang Bangun Sistem Informasi Manajemen Pengelolaan dan Penjadwalan Layanan Konsultasi Bantuan Hukum pada LBH Makassar (UIN Alauddin Makassar). UIN Alauddin Makassar. Retrieved from http://repositori.uinalauddin.ac.id/3547/

Mustaqbal, M. S., Firdaus, R. F., \& Rahmadi, H. 
(2015). PENGUJIAN APLIKASI MENGGUNAKAN BLACK BOX TESTING BOUNDARY VALUE ANALYSIS ( Studi Kasus: Aplikasi Prediksi Kelulusan SNMPTN ). Jurnal Ilmiah Teknologi Informasi Terapan, I(3), 31-36. https://doi.org/https://doi.org/10.33197/jitter. vol1.iss3.2015.62

Rosyada, A., Warassih, E., \& Herawati, R. (2018). Perlindungan Konstitusional terhadap Kesatuan Masyarakat Hukum Adat dalam Mewujudkan Keadilan Sosial. Kanun Jurnal Ilmu Hukum, 20(1), 1-22. https://doi.org/10.24815/kanun.v20i1.10021

Setyowati, H., \& Muchiningtias, N. (2018). PERAN ADVOKAT DALAM MEMBERIKAN BANTUAN HUKUM KEPADA MASYARAKAT DALAM PERSPEKTIF HAK ASASI MANUSIA. Lex Scientia Law Review, 2(2), 155-168. https://doi.org/10.15294/lesrev.v2i2.27582

Sidiq, A. H., \& Kurniawati, A. (2019). ANALISIS KEBUTUHAN SISTEM ADMINISTRASI BAGIAN SIDANG UJIAN UNIVERSITAS GUNADARMA DENGAN METODE PIECES. Jurnal Ilmiah Teknologi Dan Rekayasa, 24(1), 22-34. https://doi.org/10.35760/tr.2019.v24i1.1931

Soeherman, B., \& Pinontoan, M. (2018). Designing Information System. Jakarta: Elex Media Komputindo.

Supriyatna, A., \& Maria, V. (2018). Analisa Tingkat Kepuasan Pengguna dan Tingkat Kepentingan Penerapan Sistem Informasi DJP Online dengan Kerangka PIECES. Khazanah Informatika: Jurnal Ilmu Komputer Dan Informatika, 3(2), 88. https://doi.org/10.23917/khif.v3i2.5264

Tullah, R., \& Hanafri, M. I. (2014). Evaluasi Penerapan Sistem Informasi Pada Politeknik LP3I Jakarta Dengan Metode Pieces. Jurnal Sisfotek Global, 4(1), 22-28. 
Volume 7, Edisi 1, November 2020

$\mathbf{1 6} \mid \mathrm{H}$ a $1 \mathrm{a}$ m a 